\title{
AYURLOG
}

National Journal of Research in Ayurved Science

http://www.ayurlog.com

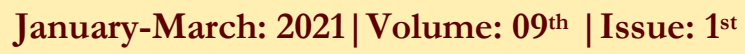

ISSN: $2320-7329$

\section{Conceptual study on effect of Krauncha Beeja (Mucuna pruriens) Churna on serum prolactin levels and sperm count vis a vis Bromocriptine.}

Namrata Mangesh Patil*¹, Mangesh Laxman Patil ${ }^{2}$, Binal Kolekar $^{3}$, Prathmesh Dhamal ${ }^{4}$

1. Associate Professor, Dept. of Kaumarbhritya, B.R. Harne Ayurved Medical College, Maharashtra, India.

2. Associate Professor, P.G. Guide, PhD. Guide, Dept. of Prasuti tantra \& Stree roga , Y.M.T. Ayurved Medical College, Kharghar, Navi Mumbai, Maharashtra, India.

3, 4. PG Scholar, Dept Of Prasuti tantra \& Stree roga, Y.M.T. Ayurved Medical College,kharghar, Navi Mumbai, Maharashtra, India.

*Corresponding author: drnamratathorat@gmail.com

\section{Abstract:-}

Hyperprolactinemia is detected in patients with infertility, impotence and hypogonadism. It is caused by or is associated with variety of pathological conditions such as pituitary adenoma, hypothalamic disorders, hypothyroidism, adrenocortical tumour etc. If hyperprolactinemia is the reason of Oligozoospermia then bromocriptine administration will improve sperm count. $^{[5]}$
Kraunch Beeja has been described to be useful in various diseases of reproductive system in books of Indian medicines (Ayurveda). Clinical research proves its effect on reduction of hyperprolactinemia. As it works on prolactin levels it can be used to treat both Oligozoospermia and Galactorrhoea.

The purpose of this study is to overview the effect of Krauncha Beeja Churna on Sr. Prolactin levels 
and Sperm count, like the effect of Bromocriptine. So that we can propose the use Krauncha Beeja Churna instead of Bromocriptine to control hyperprolactinemia and enhance sperm count.

Keywords - Hyperprolactinemia, Oligozoospermia, Bromocriptine, Prolactin, Sperm count.

\section{Introduction-}

Infertility is defined as a failure to conceive within one or more years of regular unprotected coitus. One of the main cause for male infertility is low sperm count i.e. Oligospermia. Hyperprolactinemia is amongst the endocrine disorders known to influence male infertility.

Hyperprolactinemia in men is defined by the presence of high serum prolactin levels. It can result from physiological or pathological conditions. Stress and exercise can cause small increase in prolactin levels and are important causes of physiological hyperprolactinemia. ${ }^{[2]}$
Previous studies have indicated that stress especially psychological stress, have negative impact on various parameters associated with sperm quality; including sperm concentration, motility and morphology. Chronic exposure to psychological stress is also known to cause variety of pathophysiological changes in neuroendocrine system resulting in altered steroidogenesis and spermatogenesis.

Bromocriptine is generally used to treat hyperprolactinemia but also has its effect on sperm count. It increase the sperm count in the patients with hyperprolactinemia. Krauncha Beeja is well known for its Aphrodisiac nature and its influence on the production of Testosterone. The classical texts highlight multiple formulations where this herb has been the choice and member of aphrodisiac and male infertility. It is a renowned potential herb used in the treatment of low sperm count. It is also used as a treatment protocol in hyperprolactinemia.

Macroscopic and Microscopic feature of Kraunch Beeja. ${ }^{[3]}$

\begin{tabular}{|l|l|}
\hline Macroscopic feature & Microscopic feature \\
\hline Seeds- The colour of the seeds & Seeds- Outermost is a single layer with cells \\
is dark brown along with the & similar to palisade cells. Followed by inner 2/3 \\
spots; usually observed with & layers of testa (outer layer consist of thin walled, \\
$1.2-1.8$ cm length, 0.8-1.2cm & ovoid tangentially long cells; inner layer may be \\
\hline
\end{tabular}




\begin{tabular}{|l|l|}
\hline $\begin{array}{l}\text { width. They are smooth at } \\
\text { touch, hard, difficult to break; } \\
\text { with indistinct odour, and } \\
\text { sweetish - bitter-taste. }\end{array}$ & $\begin{array}{l}\text { thick walled, beaker or dumb shaped, cells); } \\
\text { tegmen is formed by oval shaped, compressed, } \\
\text { thin walled parenchymatous cells (some may } \\
\text { contain starch grains); cotyledons is formed by } \\
\text { thin walled, angular, polygonal, closely arranged, } \\
\text { parenchyma cells, possessing starch and aleurone } \\
\text { grains; starch grains are usually small, simple, } \\
\text { oval or rounded; a few vascular bundles may also } \\
\text { be observed along with vessels exhibiting } \\
\text { reticulate thickening or pitted surface. }\end{array}$ \\
\hline
\end{tabular}

\section{PROBABLE MODE OF ACTION OF KRAUNCHA BEEJA CHURNA}

Krauncha Beeja Churna is a rich source of L-DOPA and the metabolites, which includes epinephrine and norepinephrine. It may be linked with the activation of $\beta$-adrenergic system by increasing cyclic adenosine monophosphate (cAMP) levels, which in turn regulate carbohydrate metabolism, lipolysis of fat and functioning of genitourinary and gastrointestinal tracts. Levels of cAMP acts on oligozoospermic men; and shows its effect on sperm count. ${ }^{[1]}$

Krauncha Beeja Churna possess significantly antiparkinson activity compared with Levodopa. Krauncha Beeja Churna restores the endogenous levodopa, dopamine, norepinephrine and serotonin content in substantia nigra. ${ }^{[7]}$ The degenerating dopaminergic neurons in substantia nigra may increase complex-I activity. The neurorestorative action is the additional finding which has its effect on PRL modulators. ${ }^{[6]}$

\section{DISCUSSION-}

Bromocriptine treatment $2.5 \mathrm{mg}-7.5 \mathrm{mg}$ daily for 8 -16weeks lowers the raised prolactin levels and brings it to normal levels, according to the available research publication in patients with oligosthenospermia, bromocriptine showed marked increase in sperm count and sperm motility. Bromocriptine induced suppression of Sr. PRL allows the circulating gonadotropins act on the gonads, thus stimulating steroidogenesis.

Krauncha Beeja Churna is taken in dose of 3-6gms per day for 3 months. It helps in some way against stress , L -dopa is the main chemical constituent of Krauncha Beeja which 
has dopaminergic action which shows its effect on hypothalamo- pituitary gonadal axis. L-dopa the main phenolic phyto constituent ensures this herb to be the national herb of choice in male infertility. ${ }^{[2]}$ L- dopa also has its action on hyperprolactinemia which shows its effect on increasing sperm count and root cause of infertility gets cured and facilitate conception.

\section{CONCLUSION -}

Hormone assessment is an integral part of male infertility evaluation amongst the different components of HPG axis, prolactin plays an important role in the pathophysiology of male infertility potentially altering semen production. Hyperprolactinemia has been linked to a state of hypogonadism and a reduction in semen quantity as well as quality. Treatment of hyperprolactinemia leads to an improvement in reproduction function health and well-being. ${ }^{[4]}$

So, We can conclude from the above study that Bromocriptine shows its effect on hyperprolactinemia and is responsible for increase in sperm count, likewise according to ayurvedic classics we can conclude that Kraunch Beeja has its effect on hyperprolactinemia and increases the sperm count.

\section{Reference-}

1. Effect of Mucuna pruriens on Semen profile and biochemical parameters in seminal plasma of infertile men,

2. Mohammad Kaleen Ahmad,et al, Fertility and sterility Vol.90,No. 3 September 2008, Copyright 2008 American Society for Reproductive Medicine, Published by Elsevier Inc,

3. Mucuna pruriens Reduces stress and Improves the Quality of Semen in Infertile Men, Kamla Kant Shukla, et al,

4. Published online 2007Dec 18.doi: 10.1093/ecam/nem171

5. Exploration of traditional views for therapeutic applications of a potent indigenous aphrodisiac herb: Kapikachu (Mucuna pruriens), Manpreet Kaur, Charu Khanna* , Madhavi Sharma , 2018 JETIR December 2018, Volume 5, Issue 12.

6. Hyperprolactinaemia in male infertility : Clinical Case Scenarios, Zeinab Dabbous and Stephen Atkin, Arab J Urol. 2018 Mar ; 16(1): 44-52. 
Published Online 2017 Nov 16. doi: 10.1016/j.aju.2017.10.002

7. Infertility - Male And Female Edited by Vaclav Insler and Bruno Lunenfeld $2^{\text {nd }}$ Edition,P.no.584, Printed and bound in Great Britain by William Clowes Limited, Beccles and London.

8. Actions of Prolactin in the Brain : from Physiological
Adaptations to Stress and Neurogenesis

to Psychopathology. Luz Torner, Front Endocrinol(Lausanne). 2016; Mar $30 \quad$ doi 10.3389/fendo.2016.00025

9. Neuroprotective effects of the antiparkinson drug Mucuna pruriens, Bala V. Manyam, et al. 11october 2004, https://doi.org/10.1002/ptr.1514

\section{Cite this article:}

"Conceptual study on effect of Krauncha Beeja (Mucuna pruriens) Churna on serum prolactin levels and sperm count vis a vis Bromocriptine."

Mangesh Laxman Patil, Namrata Mangesh Patil, Binal Kolekar, Prathmesh Dhamal Ayurlog: National Journal of Research in Ayurved Science- 2021; (09) (01):01- 05 